\title{
Squamous cell carcinoma transformed from the prostatic adenocarcinoma with endocrine therapy: a case report and literature review
}

\section{Shizhang Song}

qingdao daxue: Qingdao University

Bo Jiang

Qingdao Municipal Hospital Group

Sichuan Hou

Qingdao Municipal Hospital Group

Xingang Huang

Qingdao Municipal Hospital Group

Chunmei Li

Qingdao Municipal Hospital Group

Zhijun Liu ( $\square$ qdliuzhijun@163.com )

Qingdao Municipal Hospital Group

\section{Case report}

Keywords: Prostate, Squamous cell carcinoma, Adenocarcinoma, Endocrine therapy, Transformation

Posted Date: September 20th, 2021

DOI: https://doi.org/10.21203/rs.3.rs-898475/v1

License: (c) (i) This work is licensed under a Creative Commons Attribution 4.0 International License. Read Full License 


\section{Abstract}

Background

Squamous cell carcinoma (SCC) of the prostate is a very rare and highly aggressive tumor, which is insensitive to multiple treatments, prone to metastasis, and has a worse prognosis than adenocarcinoma of the prostate. However, a transformation of prostatic adenocarcinoma into squamous cell carcinoma is rarer and may occur after endocrine or radiotherapy. By now, there are few cases in the world about the transformation from adenocarcinoma into squamous cell carcinoma after treatment. To our knowledge, our case is the first reported in China.

Case presentation

A 67-year-old man with metastatic adenocarcinoma of the prostate for 2 years, was not suitable for radical prostatectomy due to the disease classified T4N1M1. Endocrine therapy using Luteinizing Hormone-Releasing Hormone (LHRH) analog (leuprorelin) and antiandrogen agent (bicalutamide) was started, and serum prostatespecific antigen (PSA) level gradually decreased to a nadir of $0.04 \mathrm{ng} / \mathrm{ml}$. 2 years after treatment, he complained of worsening of lower urinary tract symptoms, and then he underwent transurethral resection of the prostate (TURP). Histopathological examination confirmed most of the tissue areas were accompanied by poorly differentiated keratinizing squamous cell carcinoma. Now, the patient started docetaxel treatment. He has received 2 times of systemic chemotherapy. The patient's current general condition is fair.

\section{Conclusions}

Prostatic adenocarcinoma transformed into squamous cell carcinoma after endocrine therapy is very rare. However, the serum PSA of this tumor is probably normal, PSA and the Gleason grading system are of limited value in the diagnosis of SCC, histopathological can help its diagnosis. The transformation is silent and we cannot know it. The question of whether prostatic adenocarcinoma or SCC of the prostate requires more definitive research to answer.

\section{Background}

Squamous cell carcinoma (SCC) of the prostate is an extremely rare tumor with aggressive nature, representing less than $1 \%$ of prostatic carcinomas[1]. SCC generally has a worse prognosis than adenocarcinoma because it commonly metastasizes to the bone, liver, and lungs in early time, and the median survival time is estimated to be 14 months[2]. It is worth noting that even in a metastatic SCC of the prostate, the serum prostate-specific antigen (PSA) may be within the normal range[3]. At the present, the transformation of prostatic adenocarcinoma to SCC after endocrine therapy has been reported in the literature in few cases. Here, we show a patient of SCC of the prostate transformed from the prostatic adenocarcinoma following 2 years of endocrine therapy.

\section{Case Presentation}

A 67-year-old man was admitted to the hospital for half a month of pain in the waist and hip, accompanied by lower urinary tract symptoms. Laboratory examination showed the serum PSA level was $63.38 \mathrm{ng} / \mathrm{mL}$. Chest 
computed tomography (CT) scan revealed multiple small nodules lesions in both lungs. An abdomen and pelvis CT scan were also performed, and it showed lymph node shadow in the right lower abdomen, an abnormal high-density shadow in the lumbosacral vertebra and left hip, which was suspected as tumor metastasis. Prostatic MRI showed typical imaging features of prostate cancer (Fig. 1A, B). Unfortunately, his bone scan was positive (Fig. 1C). Subsequent transrectal ultrasound guided needle biopsy concluded to Gleason $10(5+5)$ prostatic adenocarcinoma (Fig. 2). Our patient was not suitable for radical prostatectomy due to the disease classified T4N1M1. Endocrine therapy using LHRH analogue (leuprorelin) and antiandrogen agent (bicalutamide) were started, and serum PSA level gradually decreased to a nadir of $0.04 \mathrm{ng} / \mathrm{ml}$. After a subsequent follow-up of 15 months, abdominal CT showed that his bladder was invaded by a tumor (Fig. 3). 2 years after treatment, he complained worsening of lower urinary tract symptoms. And then he underwent transurethral resection of the prostate (TURP). Histopathological examination confirmed most of the tissue areas were accompanied by poorly differentiated keratinizing squamous cell carcinoma and with neuroendocrine differentiation in the local areas (Fig. 4A). Immunohistochemical staining showed that almost all tumor cells are positive for p40, p63 and CD138 (Fig. 4B, C). Ki67 was detected in about 70\% of the tumor cells. His symptoms of the lower urinary tract were improved after TURP, but the prostatic adenocarcinoma was proved to transform into SCC. The patient started docetaxel treatment. So far, he has received 2 times of systemic chemotherapy. The patient's current general condition is fair.

\section{Discussion}

Squamous cell carcinoma (SCC) of the prostate is a very rare and highly aggressive tumor, representing less than $1 \%$ of prostatic carcinomas[1,3]. The age of onset of SCC is mostly about 40 to 80 years old, and the median survival time after diagnosis is estimated to be 14 months[4]. The clinical features of SCC of the prostate and adenocarcinoma of the prostate are quite different, and the SCC of the prostate of patient's symptoms are similar to those of advanced prostatic adenocarcinoma, including lower urinary tract symptoms (LUTS), acute urinary retention, and bone metastases, among which bone metastases are mainly osteolytic rather than osteoblastic, which can lead to pain associated with bone metastases[5]. Due to SCC of the prostate differs from adenocarcinoma in its therapeutic response and prognosis. It usually with a poor response to conventional treatment and with a poor prognosis[6]. Because of high degree of malignancy, SCC of the prostate commonly metastasizes to other organs in early time. As well, the serum PSA may be within the normal range in SCC of the prostate, PSA and the Gleason grading system are of limited value in the diagnosis of SCC, histopathological can help its diagnosis[7-9].

The etiology of SCC remains unclear. It may originate from the prostatic or bladder urethral squamous cell, prostatic acini metaplasia, or squamous metaplasia of a prostatic urethral primary tumor $[4,10]$. Regarding the occurrence and progression of cancer, it is proposed that cancer stem cells with the ability of self-replication, multi-differentiation and tumor formation are the origin, which can form pluripotent stem cells capable of multidirectional differentiation or metaplastic transformation of adenocarcinoma[11]. It has been suggested that SCC developed was a result of adverse stimuli affecting columnar cells causing them to express normal prostatic antigen such as PSA and prostatic acid prophatase (PAP), although retaining the ability to produce keratin[12]. Some reported transformation of adenocarcinoma to SCC occurred secondary to radiation or endocrine treatment. And the transformation often occurs in high-grade prostatic adenocarcinoma[7, 8]. Our case fits this situation. Recently, Hubert et al[13] detected a TMPRSS2-ERG fusion, among other genetic 
alterations, by comprehensive genomic profiling (CGP), supporting a diagnosis of metastatic SCC transformed from prostatic adenocarcinoma following androgen deprivation therapy (ADT).

Until now, there are a few cases about prostatic adenocarcinoma transformed into squamous cell carcinoma through endocrine therapy since Braslis et al[8] first reported in 1995. To our knowledge, our case is the first reported in China. In 2004, Parwani et al[4] reported 33 cases of prostate cancer with squamous differentiation, 21 of which had a history of adenocarcinoma diagnosis before treatment, and of these 21 cases, a total of 9 had a history of endocrine therapy (8 cases treated with endocrine therapy alone and 1 case treated with endocrine therapy and radiation). And in 2019, Hamza et al[2] retrospectively analyzed more than 70 cases of prostate cancer with squamous differentiation. 40 of these cases were caused by the transformation of prostatic adenocarcinoma into SCC after radiation therapy (RT) or endocrine therapy. There were 8 cases of purely epidermoid carcinoma alone and 32 cases of adenosquamous carcinoma. In their review, the further suggests a possible link between the transformation of prostatic adenocarcinoma into SCC and endocrine therapy. Our patient was diagnosed with metastatic prostatic adenocarcinoma that transformed into SCC of the prostate after 2 years of endocrine therapy. There are 6 cases reported in the English literature in the last 10 years of prostatic adenocarcinoma transformed into squamous cell carcinoma by endocrine therapy. We reviewed these cases and our case in Table 1. 4 of these cases did not undergo radical prostatectomy and received endocrine therapy and eventually transformed into SCC of the prostate. Moreover, the duration of treatment of endocrine therapy is different in each case, it is uncertain from which point in time differentiation to squamous epithelial carcinoma begins to occur. Leuprorelin and bicalutamide in our patient resulting a decrease in the level of androgens in the patient's blood. Which may affect the loss of the ability of the prostatic columnar cells to express PSA and PAP, while the ability of the prostate to produce keratin remains, thus facilitating transformation. 
Table 1

Published cases about transformation of prostatic adenocarcinoma into SCC after endocrine therapy in the last 10 years

\begin{tabular}{|c|c|c|c|c|c|c|c|}
\hline & Reference & Year & $\begin{array}{l}\text { Age } \\
\text { (yr.) }\end{array}$ & $\begin{array}{l}\text { Initial } \\
\text { PSA(ng/ml) }\end{array}$ & GS & $\begin{array}{l}\text { Rdical } \\
\text { prostatectomy }\end{array}$ & Endocrine therapy therapy time \\
\hline 1 & $\begin{array}{l}\text { Al- } \\
\text { Qassim } \\
\text { et al[4] }\end{array}$ & 2014 & 65 & 84.5 & $\begin{array}{l}4 \\
+ \\
5 \\
= \\
9\end{array}$ & No & $\begin{array}{l}\text { LHRH analogue (Leuprorelin) } 18 \\
\text { months }\end{array}$ \\
\hline 2 & $\begin{array}{l}\text { Lee et } \\
\text { al[1] }\end{array}$ & 2019 & 76 & 1.27 & $\begin{array}{l}4 \\
+ \\
5 \\
= \\
9\end{array}$ & No & $\begin{array}{l}\text { LHRH analogue (goserelin) and } \\
\text { antiandrogenagent(bicalutamide) } \\
7 \text { months }\end{array}$ \\
\hline 3 & $\begin{array}{l}\text { Ichaoui et } \\
\text { al[2] }\end{array}$ & 2019 & 71 & 2.7 & $\begin{array}{l}3 \\
+ \\
3 \\
= \\
6\end{array}$ & Yes & $\begin{array}{l}\text { LHRH ananlogue(Triptorelin) } 6 \\
\text { months }\end{array}$ \\
\hline 4 & $\begin{array}{l}\text { Dizman } \\
\text { et al[14] }\end{array}$ & 2020 & $\nabla 76$ & 44.7 & $\begin{array}{l}4 \\
+ \\
4 \\
= \\
8\end{array}$ & No & $\begin{array}{l}\text { CYP17 inhibitor and LHRH } \\
\text { analogue(Leuprorelin) } 3 \text { years }\end{array}$ \\
\hline 5 & & & $\nabla 60$ & 9.9 & $\begin{array}{l}5 \\
+ \\
4 \\
= \\
9\end{array}$ & Yes & $\begin{array}{l}\text { LHRH analogue (Leuprorelin)and } \\
\text { CYP17 inhibitor(Abiraterone) } 2 \\
\text { months }\end{array}$ \\
\hline 6 & $\begin{array}{l}\text { Lau et } \\
\text { al[13] }\end{array}$ & 2020 & 68 & $\mathrm{~N} / \mathrm{A}$ & $\begin{array}{l}3 \\
+ \\
4 \\
= \\
7\end{array}$ & Yes & $\begin{array}{l}\text { LHRH analogue (Leuprorelin) and } \\
\text { antiandrogen agent } \\
\text { (bicalutamide) } 8 \text { months }\end{array}$ \\
\hline 7 & Our case & 2021 & 67 & 63.38 & $\begin{array}{l}5 \\
+ \\
5 \\
= \\
10\end{array}$ & No & $\begin{array}{l}\text { LHRH analogue (Leuprorelin) and } \\
\text { Bilateral Orchidectomy } 27 \\
\text { months }\end{array}$ \\
\hline
\end{tabular}

Imaging diagnosis of SCC of the prostate is challenging due to it is extremely rare and lack of well-established imaging characteristics[1]. Currently, the treatment of primary SCC of the prostate is unclear and is mostly a combination of surgical therapy, radiotherapy and chemotherapy. For patients who have lost the opportunity for surgical therapy, a combination of chemotherapy and radiation therapy may be effective for SCC of the prostate. Biswas et al[15] reported a patient with primary SCC of the prostate staged as T4N1M0, who received chemotherapy regimen included Mitomycin C and 5-Fluoro-uracil (5FU) and low-dose radiotherapy. The patient 
is doing well after treatment, with no progression for 27 months of follow-up. Onoda M et al[16] reported a case of locally advanced SCC of the prostate treated with a combination of docetaxel, cisplatin, and 5fluorouracil chemotherapy and radiotherapy. The patient showed good responsiveness after treatment with no progression for 24 months of follow-up. Recently, Hanna K et al[17] reported a case of primary SCC of the prostate staged as T4N1M1. The patient is currently undergoing four cycles of adjuvant docetaxel and carboplatin. There is also no optimal treatment for SCC of the prostate transformed from prostatic adenocarcinoma during endocrine therapy. Based on the pathological diagnosis and the imaging, the decision was made to pursue adjuvant chemotherapy, and the patient is currently undergoing two cycles of adjuvant docetaxel. Dizman N et al[14] have conducted CGP on the squamous transformation of prostate adenocarcinoma, suggested that CGP could play an essential role in clinical practice to identify the origin and targeted therapy of the squamous transformation.

\section{Conclusions}

Prostatic adenocarcinoma transformed into squamous cell carcinoma after endocrine therapy is very rare. However, the serum PSA of this tumor is probably normal, PSA and the Gleason grading system are of limited value in the diagnosis of SCC, histopathological can help its diagnosis. The transformation is silent and we cannot know of it. The question of whether prostatic adenocarcinoma or SCC of the prostate requires more definitive research to answer. Our case should be useful for further studies of this aggressive tumor.

\section{Abbreviations}

SCC: Squamous cell carcinoma; LHRH: Luteinizing Hormone Releasing Hormone; PSA: Prostate specific antigen; TURP: Transurethral resection of the prostate; CT: Computed tomography; LUTS: Lower urinary tract symptoms; PAP: Prostatic acid prophatase; CGP: Comprehensive genomic profiling; ADT: Androgen deprivation therapy; RT: radiation therapy; 5FU:5-Fluoro-uracil; N/A: not mentioned in literature; GS: Gleason score.

\section{Declarations}

\section{Ethics approval and consent to participate}

Not applicable

\section{Consent to publish}

Written informed consent was obtained from the patient for publication of this Case report and any accompanying images. A copy of the written consent is available for review by the Editor of this journal.

\section{Availability of data and materials}

Data and records pertaining to this case are in the patient's secure medical records in the Qingdao Municipal Hospital. All searched data by literature review are included in this paper.

\section{Competing interests}


The authors declare that they have no competing interests.

\section{Funding}

No funding support.

\section{Authors' contributions}

SZS and BJ were the patients' Urologists, reviewed the literature and contributed to manuscript drafting; $\mathrm{SCH}$ conceptualized the case report; XGH diagnosed the case by histopathology; CML diagnosed the case by imaging; ZJL revised and edited the manuscript. All authors read and approved the final manuscript.

\section{Acknowledgements}

Not applicable.

\section{Author details}

${ }^{1}$ Department of Urology, Qingdao Municipal Hospital, Qingdao University, Qingdao 266001, Shandong, China.

${ }^{2}$ Department of Pathology, Qingdao Municipal Hospital, Qingdao University, Qingdao 266001, Shandong, China.

${ }^{3}$ Department of Radiology, Qingdao Municipal Hospital, Qingdao University, Qingdao 266001, Shandong, China

\section{References}

1. Lee J. Transformation of adenocarcinoma of prostate to squamous cell carcinoma following hormonal treatment: A case report and review of the literature. Radiol Case Rep. 2019;14(4):483-9.

2. Ichaoui H, Nasr SB, Gargouri F, Zribi A, Hermi A, Fendri S, Balti M, Ayari J, Khiari R, Msakni I, et al. Transformation of a prostatic adenocarcinoma into squamous cell carcinoma after luteinizing hormonereleasing hormone (LHRH) agonist and radiotherapy treatment. Pan Afr Med J. 2019;34:125.

3. Di Pietro C, Celia A, De Stefani S, Saredi G, Bianchi G. Squamous cell carcinoma of the prostate. Arch Ital Urol Androl. 2006;78(2):75-6.

4. Parwani AV, Kronz JD, Genega EM, Gaudin P, Chang S, Epstein JI. Prostate carcinoma with squamous differentiation: an analysis of 33 cases. AM J SURG PATHOL. 2004;28(5):651-7.

5. Malik RD, Dakwar G, Hardee ME, Sanfilippo NJ, Rosenkrantz AB, Taneja SS. Squamous cell carcinoma of the prostate. Rev Urol. 2011;13(1):56-60.

6. Imamura M, Nishiyama H, Ohmori K, Nishimura K. Squamous cell carcinoma of the prostate without evidence of recurrence 5 years after operation. UROL INT. 2000;65(2):122-4.

7. Al-Qassim Z, Mohammed A, Payne D, Stocks PJ, Khan Z. Squamous cell carcinoma of the prostate following treatment with an LHRH-agonist: a rare case of transformation of adenocarcinoma of the prostate. Cent European J Urol. 2014;67(1):26-8.

8. Braslis KG, Davi RC, Nelson E, Civantos F, Soloway MS. Squamous cell carcinoma of the prostate: a transformation from adenocarcinoma after the use of a luteinizing hormone-releasing hormone agonist 
and flutamide. UROLOGY. 1995;45(2):329-31.

9. Grignon DJ. Unusual subtypes of prostate cancer. Mod Pathol. 2004;17(3):316-27.

10. Wernert N, Goebbels R, Bonkhoff H, Dhom G. Squamous cell carcinoma of the prostate. HISTOPATHOLOGY. 1990;17(4):339-44.

11. Arva NC, Das K. Diagnostic dilemmas of squamous differentiation in prostate carcinoma case report and review of the literature. DIAGN PATHOL. 2011;6:46.

12. Lager DJ, Goeken JA, Kemp JD, Robinson RA. Squamous metaplasia of the prostate. An immunohistochemical study. AM J CLIN PATHOL. 1988;90(5):597-601.

13. Lau HD, Clark M. Metastatic squamous cell carcinoma transformed from prostatic adenocarcinoma following androgen deprivation therapy: A case report with clinicopathologic and molecular findings. DIAGN CYTOPATHOL. 2020;48(12):E14-7.

14. Dizman N, Salgia M, Ali SM, Wu H, Arvanitis L, Chung JH, Pal SK. Squamous Transformation of Prostate Adenocarcinoma: A Report of Two Cases With Genomic Profiling. Clin Genitourin Cancer. 2020;18(3):e289-92.

15. Biswas T, Podder T, Lepera PA, Walker P. Primary squamous cell carcinoma of the prostate: a case report of a rare clinical entity. Future Sci OA. 2015;1(3):018.

16. Onoda M, Sugimoto R, Uesugi N, Takayama M, Shiomi E, Kato R, Kato Y, Takata R, Omori S, Obara W. Novel combination chemotherapy with radiotherapy for prostate squamous cell carcinoma. Int Cancer Conf J. 2017;6(1):25-8.

17. Hanna K, Lele SM, McCormick G, McMahon A, Hill B, Boyle SL. Primary prostatic squamous cell carcinoma. Urol Case Rep. 2021;34:101478.

\section{Figures}

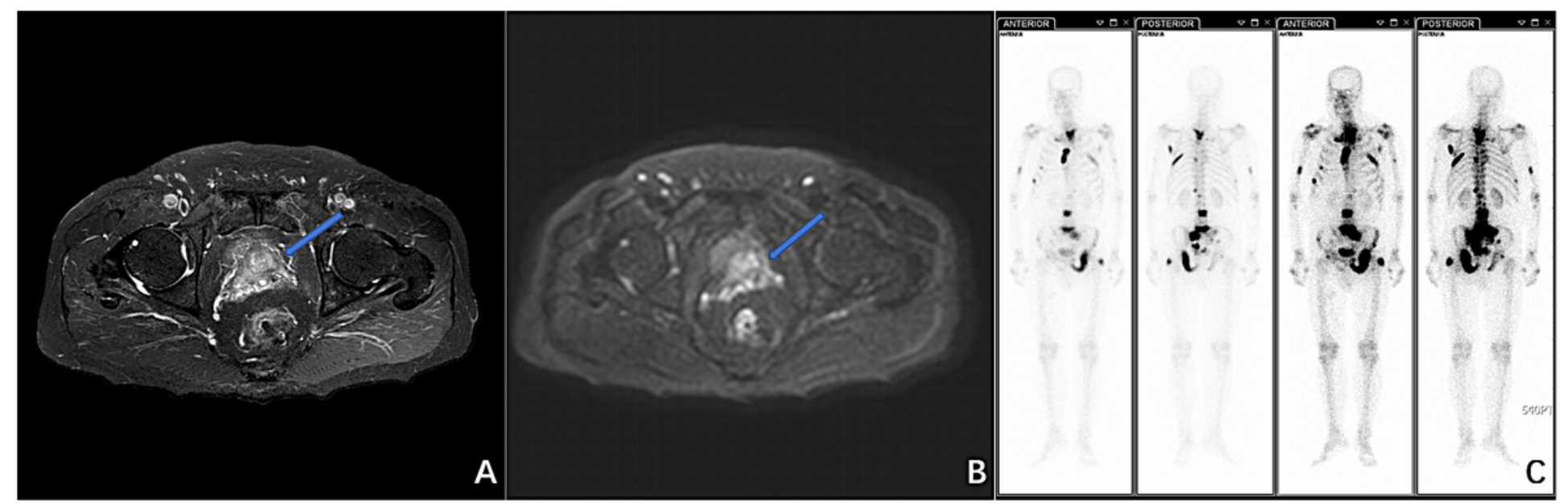

\section{Figure 1}

A MRI (T2-weighted image) showing a mass lesion in the left peripheral zone. B MRI (apparent diffusion coefficient) showing a mass lesion in the left peripheral zone. C Bone scintigraphy showing multiple metastases. 


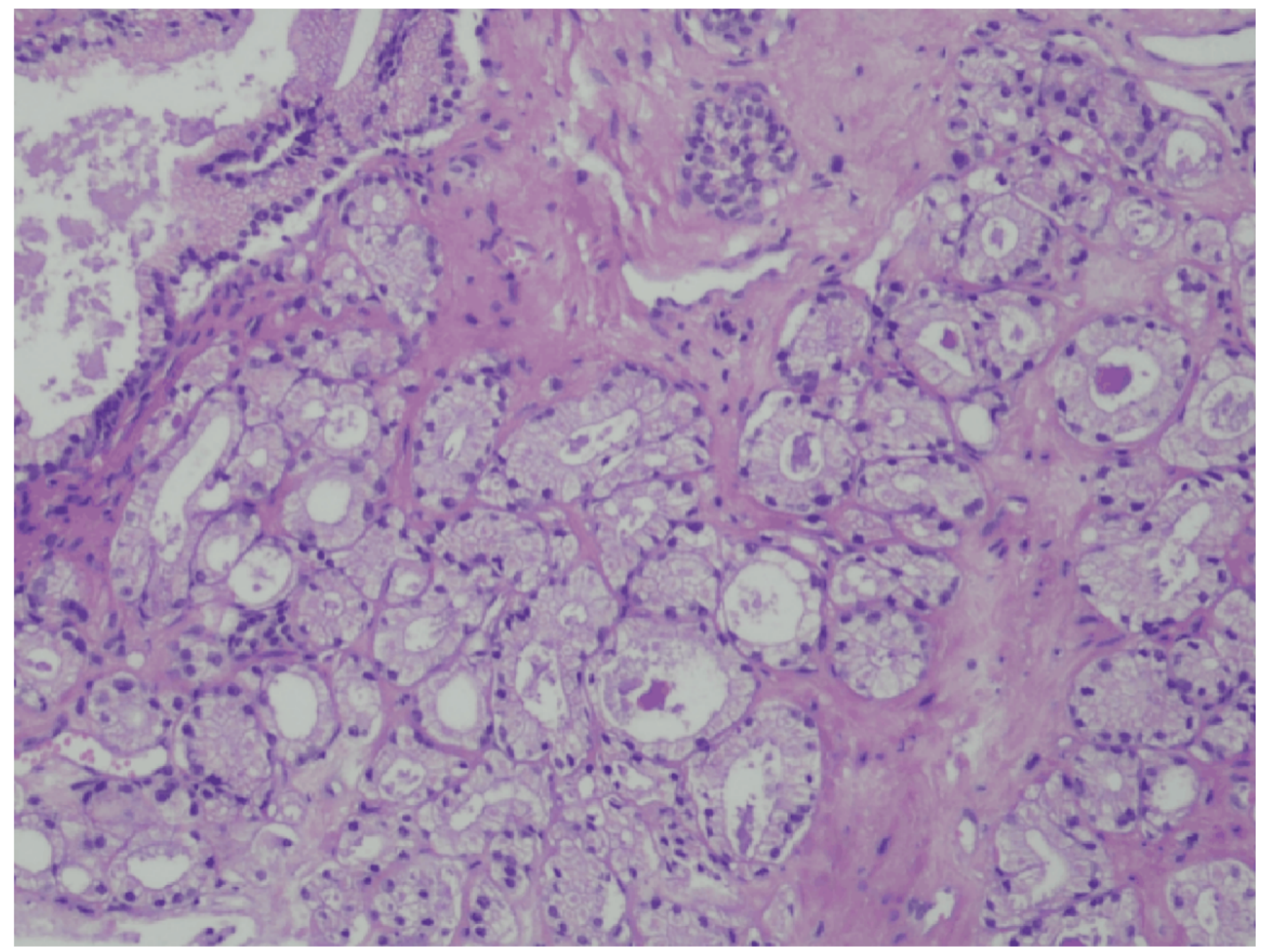

\section{Figure 2}

Initial biopsy form prostate mass showing acinar adenocarcinoma, Gleason $5+5=10$ (H\&E, original magnification $\times 100$ ) 


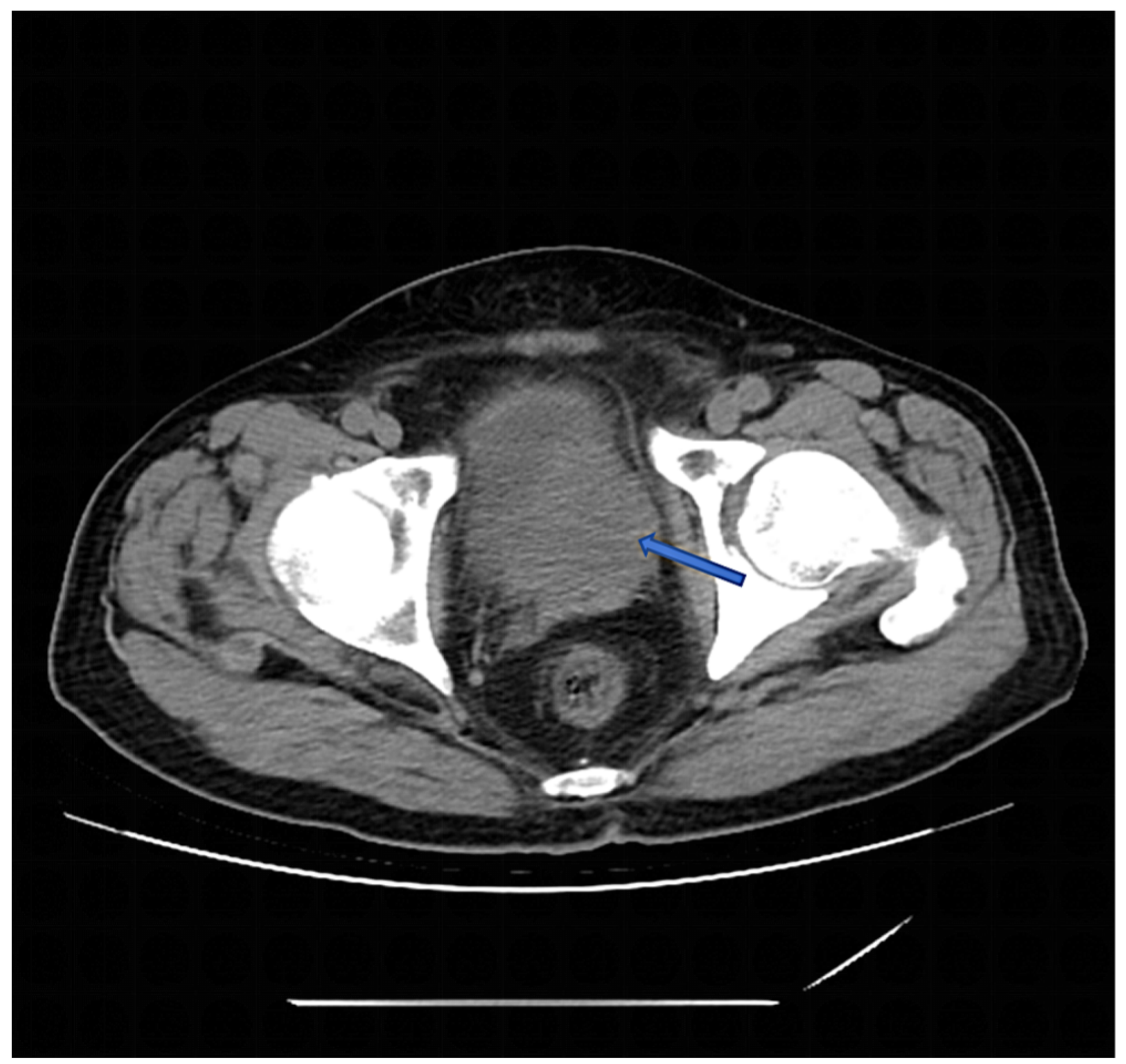

Figure 3

Abdominal CT showing that the bladder was invaded by a solid lesion 

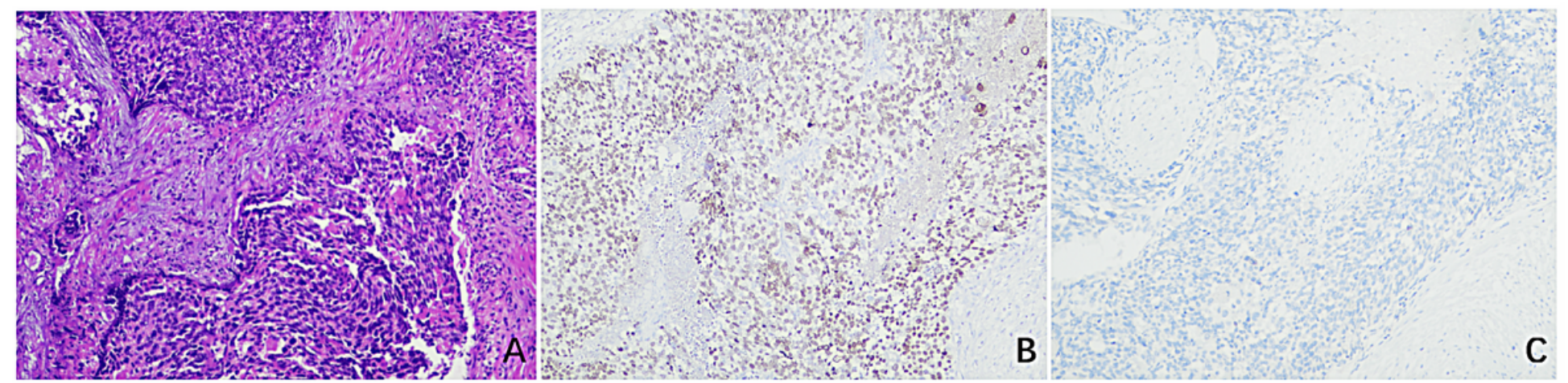

\section{Figure 4}

A Later trans urethral resection of the prostate chips showing poorly differentiated keratinizing squamous cell carcinoma and with neuroendocrine differentiation in the local areas(H\&E, original magnification $\times 100)$. Immunohistochemical staining showed that tumor cells are positive for $\mathrm{p} 63(\mathrm{~B})$ and $\mathrm{p} 40(\mathrm{C})$. (immunoperoxidase $\times 100$ ). 